\title{
Tobacco control in Asia-Pacific: wins, challenges and targets
}

\author{
Judith Mary Mackay 다. 1,2 E Ulysses Dorotheo, ${ }^{3}$ Mary Assunta, ${ }^{4,5}$ \\ Bungon Ritthiphakdee ${ }^{6}$
}

${ }^{1}$ Director, Asian Consultancy on Tobacco Control, Hong Kong, SAR China

${ }^{2}$ Special Advisor, Global Center for Good Governance in

Tobacco Control (GGTC), Hong Kong, SAR China

${ }^{3}$ Executive Director, Southeast Asian Tobacco Control Alliance (SEATCA), Manila, Philippines ${ }^{4}$ Senior Advisor, Southeast Asia Tobacco Control Alliance (SEATCA), Sydney, New South Wales, Australia

${ }^{5}$ Head of Research and Advocacy, Global Center for Good Governance in Tobacco Control (GGTC), Sydney, New South Wales, Australia

${ }^{6}$ Executive Director, Global Center for Good Governance in Tobacco Control (GGTC), Bangkok, Thailand

\section{Correspondence to}

Professor Judith Mary Mackay, Director, Asian Consultancy on Tobacco Control, Hong Kong, Hong Kong: jmackay1@netvigator.com

Received 23 May 2021 Accepted 29 October 2021

\section{Check for updates}

(C) Author(s) (or their employer(s)) 2022. No commercial re-use. See rights and permissions. Published by BMJ.

\footnotetext{
To cite: Mackay JM, Dorotheo EU, Assunta M, et al. Tob Control 2022;31:146-149.
}

\section{ABSTRACT}

For many decades, the international tobacco industry has set its sights on Asia, due to the large population numbers, the high prevalence of male smokers who might shift to its brands, and the extremely low number of female smokers who could possibly be induced into starting smoking. Because of US trade threats against several Asian countries in the 1980s, Asia became quickly aware that tobacco control involved politics, legislation, economics and trade. Several Asian jurisdictions pioneered tobacco control measures, and the Western Pacific is still the only WHO region where all countries have ratified the WHO Framework Convention on Tobacco Control (FCTC). Progress needs to be accelerated to reduce the still high male smoking prevalence and maintain the low female prevalence by fully implementing the WHO FCTC as part of achieving sustainable development, even while grappling with the looming epidemic of new products, holding the companies accountable, and protecting tobacco control policies against constant industry interference.

'You know what we want? We want Asia.'

-Tobacco industry executive, $1988^{1}$

Huge populations of existing Asian male smokers, smoking mainly locally produced cigarettes, plus the potential of inducing Asian women to start smoking, led the Vice-President of Philip Morris Asia to forecast in 1986: 'Bright Future Predicted for Asia Pacific'. ${ }^{2}$ Rothmans similarly enthused in 1992: 'Thinking about Chinese smoking statistics is like trying to think about the limits of space.'

'Asia-Pacific' covers Brunei, Cambodia, China, Hong Kong and Macao, Indonesia, Japan, Lao PDR (People's Democratic Republic), Malaysia, Mongolia, Myanmar, Philippines, Republic of Korea, Singapore, Thailand and Vietnam.

Currently, half the world's tobacco is grown and consumed in Asia. Male smoking rates remain generally high but, since 1980, have been halved in Hong Kong, Japan and Singapore. The traditionally low female rates have not risen as was feared they might. ${ }^{4}$ However, electronic cigarette and heated tobacco product use is increasing, especially among youth, leading to a major current challenge for Asia, ${ }^{5-7}$ especially with the industry misusing harm reduction as a strategy to whitewash its corporate image. ${ }^{89}$

\section{ASIA-PACIFIC: A TOBACCO CONTROL PIONEER}

Asia is a tobacco control pioneer: in 1970 Singapore became the first country in the world to

\section{What this paper adds}

- A brief but composite history of tobacco issues in the Asia-Pacific region.

- The latest status of tobacco control in the region, including tobacco industry interference.

- The need for long term tobacco control plans and Endgame targets for the region.

- The need to fully implement WHO FCTC Article 5.3 in all three branches of government-the executive, the legislative and the judiciary.

introduce national smoke-free legislation ${ }^{10}$ followed by the first (at the time) comprehensive bans on tobacco advertising in $1971 .^{11}$ The earliest significant research on secondhand smoke came from Japan: Hirayama's 1981 cohort study on passive smoking among 91000 non-smoking married Japanese women, showing that wives of heavy smokers had a higher risk of lung cancer than wives of non-smokers. ${ }^{12}$ The tobacco industry tried unsuccessfully to discredit Hirayama's paper. ${ }^{13} 14$ The government-funded Hong Kong Council on Smoking and Health was established in $1987,{ }^{15}$ the same year that Hong Kong became the first jurisdiction in the world to ban manufacture, importation and sale of smokeless tobacco products. ${ }^{16}$ In 1991, Singapore was also the first country to ban incoming duty-free cigarettes. ${ }^{4}$

Another global first was the Philippines' Joint Memorandum Circular on the 'Protection of the bureaucracy against tobacco industry interference' issued in 2010 in compliance with WHO Framework Convention on Tobacco Control (FCTC) Article 5.3. ${ }^{17}$

\section{BACK TO THE PAST TO UNDERSTAND THE PRESENT}

In the 1980s, the US Trade Representative (USTR) threatened various Asian jurisdictions with trade sanctions unless they opened their markets to American cigarettes. ${ }^{18}$ Japan, the Republic of Korea and Taiwan bowed to US pressure. While the Thai market eventually had to open to US cigarettes, Thailand successfully retained the right to ban advertising of both national and international brands. ${ }^{19}$ A 1996 study from the National Bureau of Economic Research showed that per capita cigarette consumption in the four jurisdictions was nearly $10 \%$ higher than it would have been if markets had stayed closed to American cigarettes. ${ }^{20}$

The USTR challenge galvanised Asia's tobacco control efforts and led to the early realisation that 
tobacco control involved politics, legislation, economics and trade. It also showed very clearly that the tobacco industry was the vector of this epidemic, and only by tackling the industry, its allies and its commercial and political supporters, could tobacco control be successful. ${ }^{4}$

Building upon this over the last 30 years, the WHO's Western Pacific Region is the only WHO region where all countries are Parties to the WHO FCTC. ${ }^{21}$ Some countries like Singapore have very advanced tobacco policies that are arguably on par or comparable with those in other regions with a high FCTC implementation score.

Asia has shown that action to reduce the tobacco epidemic is not the prerogative of western high-income countries, and that Asian nations-including low/middle-income countries-can grasp the political nettle of tobacco control and act successfully.

\section{KEY CHALLENGES}

While the region consists of many dynamic countries with unique sets of characteristics and challenges, obstacles to tobacco control in Asia are similar to those around the world. Many of these obstacles lie with governments. They include lack of political commitment to tobacco control, inequalities within societies, more resources going to curative medicine than preventive health; a focus on short-term tobacco tax revenue but not the overall cost of tobacco to the government, employers and individual smokers; misperceived and incorrect concerns about economic losses if tobacco control measures are implemented; and a preoccupation with other events, crises or diseases that cause far fewer deaths than tobacco. Although spurred forward by entry into force of the WHO FCTC, policy progress has been slow in many countries, and no Asia-Pacific country has yet fully implemented the WHO FCTC ${ }^{22}$ explicitly mentioned as a means to achieve the UN Sustainable Development Goals. ${ }^{23}$

Looming equally large is the obstructionist tobacco industry. Internal industry documents, ${ }^{24}$ the Tobacco Industry Interference Index, ${ }^{25} 26$ and Stopping Tobacco Organisations and Products (STOP) ${ }^{27}$ all document how the industry, its allies and front groups ignore or misrepresent the evidence; promote tobacco use with advertising, promotion and corporate sponsorship, in the process building relationships with government, media, and other organisations; challenge tobacco control legislation and tax increases ${ }^{28} 29$; attack individuals, organisations and the $\mathrm{WHO}^{30}$; and mount legal challenges against governments. ${ }^{31-34}$ The companies are also involved with smuggling their own products, which opened up new markets previously dominated by government monopolies and which flood markets with cheaper cigarettes, making them more affordable to children. ${ }^{35} 36$ They even secretly employed scientists in the infamous 'Asian Whitecoat Project' to work undercover and slant the scientific data on secondhand smoke. ${ }^{37-40}$ In some Asian countries, tobacco companies promote a 'revolving door' culture by recruiting former senior government finance and trade officials. ${ }^{41}$

Over the last 30 years, many state tobacco monopolies in Asia have morphed into behaviour previously exhibited only by private transnational companies. ${ }^{42}$ The Chinese monopoly has also embarked on major global expansion, with offices and factories around the world, using the Belt and Road Initiative, and is becoming a major international player. ${ }^{43}$

Globally, as part of its broader tactic of corporate social responsibility (CSR), the industry has exploited the COVID-19

Table 1 Current tobacco epidemic situation in Asia-Pacific region

\begin{tabular}{|c|c|c|c|c|c|c|c|c|c|}
\hline Country & $\begin{array}{l}\text { Adult daily } \\
\text { smoking } \\
\text { prevalence (\%) } \\
\text { (key 1) }\end{array}$ & $\begin{array}{l}\text { FCTC } \\
\text { ratification }\end{array}$ & $\begin{array}{l}\text { M } \\
\text { Monitor tobacco use } \\
\text { and prevention policies } \\
\text { (key 2) }\end{array}$ & $\begin{array}{l}\text { P } \\
\text { Protect from tobacco } \\
\text { smoke } \\
\text { (key 3) }\end{array}$ & $\begin{array}{l}0 \\
\text { Offer cessation } \\
\text { (key 4) }\end{array}$ & $\begin{array}{l}\text { W } \\
\text { Warn: } \\
\text { pack warnings } \\
\text { (key 5) }\end{array}$ & $\begin{array}{l}\text { W } \\
\text { Warn: } \\
\text { mass media } \\
\text { (key 6) }\end{array}$ & $\begin{array}{l}\text { E } \\
\text { Enforce } \\
\text { advertising bans } \\
\text { (key 7) }\end{array}$ & $\begin{array}{l}\text { R } \\
\text { Raise taxes } \\
(\%) \\
\text { (key 8) }\end{array}$ \\
\hline Brunei & 12 & 2004 & Yes & Yes & - & Yes & - & - & $?$ \\
\hline Cambodia & 15 & 2005 & Yes & Yes & - & Yes & - & - & 26 \\
\hline China & 23 & 2005 & Yes & - & - & - & Yes & - & 55 \\
\hline $\begin{array}{l}\text { Hong Kong, SAR } \\
\text { China }\end{array}$ & 10 & 2005 & Yes & Yes & Yes & Yes & Yes & Yes & 64 \\
\hline $\begin{array}{l}\text { Macao, } \\
\text { SAR China }\end{array}$ & 10 & 2005 & Yes & Yes & Yes & Yes & - & Yes & 60 \\
\hline Indonesia & 33 & Not party & Yes & - & - & - & Yes & - & 62 \\
\hline Japan & 17 & 2004 & Yes & - & - & - & Yes & - & 61 \\
\hline $\begin{array}{l}\text { Korea, Republic } \\
\text { of }\end{array}$ & 20 & 2005 & Yes & - & Yes & - & Yes & - & 74 \\
\hline Lao PDR & 24 & 2006 & Yes & Yes & - & Yes & - & - & 12 \\
\hline Malaysia & 17 & 2005 & Yes & - & - & Yes & Yes & - & 52 \\
\hline Mongolia & 23 & 2004 & Yes & - & - & Yes & - & Yes & 45 \\
\hline Myanmar & 15 & 2004 & Yes & - & - & - & Yes & - & 50 \\
\hline Philippines & 18 & 2005 & Yes & - & Yes & Yes & - & - & 56 \\
\hline Singapore & 14 & 2004 & Yes & - & Yes & Yes & - & - & 67 \\
\hline Thailand & 17 & 2004 & Yes & Yes & - & Yes & Yes & - & 79 \\
\hline Vietnam & 20 & 2004 & Yes & - & - & Yes & Yes & - & 39 \\
\hline
\end{tabular}

Adapted from WHO Report on the Global Tobacco Epidemic 2021, Tables 1, 3 and $1.6^{55}$ with addition of Parties to FCTC, UN. ${ }^{56}$ Hong Kong and Macao SAR China data were supplied by their respective Departments of Health, October 2021.

Key 1: prevalence: adult daily smoking prevalence (2019) (rounded).

Keys 2-7: M-R: 'yes' indicates highest level of achievement.

Key 2: $\mathrm{M}-$ monitoring: recent, representative and periodical data for both adults and youth.

Key 3: P—smoke-free environments: smoking bans. All public places completely smoke-free (or at least $90 \%$ of the population covered by complete subnational smoke-free legislation).

Key 4: 0 — cessation programmes: treatment of tobacco dependence. National quit line, and both NRT and some cessation services cost covered.

Key 5 :W-health warnings on cigarette packages. Large warnings with all appropriate characteristics.

Key 6:W-mass media: anti-tobacco campaigns. National campaign conducted with at least seven appropriate characteristics including airing on television and/or radio.

Key 7: E-advertising bans: bans on advertising, promotion and sponsorship. Ban on all forms of direct and indirect advertising (or at least $90 \%$ of the population covered by subnational legislation completely banning

tobacco advertising, promotion and sponsorship).

Key 8: R-taxation: \% share of total taxes in retail price of the most widely sold brand of cigarettes.

FCTC, Framework Convention on Tobacco Control; SAR, Special Administrative Region. 
pandemic by donating medical supplies and equipment to try to shift its image from harmful industry to helpful health partner, to make and maximise contact with policymakers, ${ }^{44-46}$ and to obstruct tobacco control measures. ${ }^{47}$ Such tactics have been recorded in Indonesia, Malaysia, Philippines and Vietnam. Philip Morris Malaysia donated personal protective equipment to the Ministry of Health through a high-profile foundation, ${ }^{48}$ while the government is still deliberating e-cigarette policy. In the Philippines, as the industry stepped up its CSR, a bill to reward the business sector for CSR activities is pending in Congress, ${ }^{49}$ which if passed, will undermine the Joint Memorandum Circular protecting the bureaucracy from industry interference.

The Philip Morris-funded Foundation for a Smoke-Free World (FSFW) has distributed grants throughout Asia, buying influence and goodwill and funding front groups that attack tobacco control advocates and their work. ${ }^{50}$ The Southeast Asia Tobacco Control Alliance has denounced the FSFW, urging governments, universities and health institutions to reject partnerships with the foundation, deeming it a tool to sabotage global tobacco control. $^{51}$

\section{WHAT IS MOST NEEDED IN THE ASIA-PACIFIC REGION?}

While the region varies considerably regarding population, gross domestic product, political systems and industry structure, there are more similarities than differences: harms caused, obstacles faced-especially industry behaviour-and tobacco control actions needed. Most needed, as elsewhere, are longterm government plans and targets for tobacco control that are integrated into national sustainable development plans and that are aimed at achieving a tobacco endgame as soon as possible. This would need adequate and sustainable resources for full implementation of the WHO FCTC (both demand and supply reduction measures), underpinned by Article 5.3, which applies to all three branches of government-the executive, the legislative and the judiciary. Civil servants in all branches of government (including embassies and trade commissions) require transparency and accountability in all dealings with the industry. Among best practice examples of civil service codes of conduct for compliance with WHO FCTC Article 5.3 and for protecting national public health policy against tobacco industry interference is the Philippines. ${ }^{52}$ Constant vigilance and exposure of tobacco industry tactics, as done by the global tobacco industry watchdog, STOP ${ }^{27}$ and regularly published in the Tobacco Industry Interference Indexes ${ }^{25}$ including the dedicated Asian edition, ${ }^{26}$ need to continue and even be led by governments.

There is a continual need to pass and enforce legislation that fully denormalises the tobacco industry, such as standardised tobacco packaging with large pictorial warnings, national bans on smoking in public places and workplaces, comprehensive bans on tobacco advertising, promotion and sponsorship including CSR, prohibiting flavoured tobacco products, and progressive restrictions on retail access to tobacco products, which would include licensing tobacco retailers and limiting their number and locations, raising the minimum legal age of sale to at least 21 years old, and eventually phasing out commercial sales of tobacco products. No jurisdiction has yet reached the highest level of achievement with all categories of WHO MPOWER, as outlined in table 1.

Countries with large numbers of tobacco farmers and workers, such as China and Indonesia, ${ }^{53}$ should seriously enact policies and implement programmes that help them shift to economically viable alternative livelihoods to lift them out of poverty and industry exploitation.
Tobacco companies should pay for the damage of their current and future products. Governments should hold tobacco companies liable (WHO FCTC Article 19) for healthcare costs, harm to victims, corruption, illicit trade, environmental damage, food insecurity, child labour and other human rights violations, and more that are caused by their products and by industry tactics. ${ }^{54}$

Contributors All authors contributed to this paper.

Funding The authors have not declared a specific grant for this research from any funding agency in the public, commercial or not-for-profit sectors.

Competing interests None declared.

Patient consent for publication Not required.

Provenance and peer review Commissioned; externally peer reviewed.

\section{ORCID iD}

Judith Mary Mackay http://orcid.org/0000-0002-9593-3502

\section{REFERENCES}

1 Interview with the tobacco reporter. Report by Heise L. unhealthy alliance. world Watch, vol 1, no 5, Sep-Oct 1988: P22.

2 Scull R. Vice-President of Philip Morris Asia. 'Bright Future Predicted for Asia Pacific. World Tobacco, 1986: 35.

3 Ibison D. Rothmans' joint deal opens heavenly gates, 1992: 4.

4 Mackay J, Ritthiphakdee B, Reddy KS. Tobacco control in Asia. The Lancet 2013;381:1581-7.

$5 \mathrm{Kim} \mathrm{J}, \mathrm{Yu} \mathrm{H}$, Lee S, et al. Awareness, experience and prevalence of heated tobacco product, IQOS, among young Korean adults. Tob Control 2018;27:s74-7.

6 Jirathanapiwat W, Reyes JL. Today's teens, tomorrow's customers: Baiting youths with new tobacco products to create a new generation of addicts. Bangkok: Southeast Asia Tobacco Control Alliance, 2020. https://seatca.org/dmdocuments/WNTD\%202020\% 20report-SEATCA-Final.pdf

7 Kuwabara Y, Kinjo A, Fujii M, et al. Heat-not-burn tobacco, electronic cigarettes, and combustible cigarette use among Japanese adolescents: a nationwide population survey 2017. BMC Public Health 2020;20:741.

8 Peeters $S$, Gilmore AB. Understanding the emergence of the tobacco industry's use of the term tobacco harm reduction in order to inform public health policy. Tob Control 2015;24:182-9.

9 Dewhirst T. Co-optation of harm reduction by big tobacco. Tob Control;30:e1-3.

10 Singapore. Act 26 of 1970. smoking (Prohibition in certain places) act, chapter 310. Available: https://sso.agc.gov.sg/Act/SPCPA1992?Provlds=Xv-

11 Straits Times. Smoking controls in Singapore over the years, 2021. Available: https:// www.straitstimes.com/singapore/smoking-controls-in-singapore-over-the-years

12 Hirayama T. Non-Smoking wives of heavy smokers have a higher risk of lung cancer: a study from Japan. BMJ 1981;282:183-5.

13 Ong E, Glantz SA. Hirayama's work has stood the test of time. Bull World Health Organ 2000;78:938-9.

14 US Department of Health and Human Services. The health consequences of involuntary smoking. Report of the surgeon General. Washington, DC: Public Health Service, 1986.

15 The Hong Kong Council on smoking and health. Available: https://www.smokefree.hk/ en/content/home.do

16 Hong Kong. Smokeless tobacco products (Prohibition) regulations (cap. 132, section 55), 1987. Available: https://www.elegislation.gov.hk/hk/cap132BW

17 Republic of the Philippines. Joint memorandum circular 2010-01. protection of the bureaucracy against tobacco industry interference. Available: http://csc.gov.ph/ phocadownload/Govtlssuances/cscdoh_jmc2010_01_1.pdf

18 Mackay J. Us tobacco export to third world: third World War. J Natl Cancer Inst Monogr 1992;12:25-8.

19 Report of the GATT Panel adopted on 7 November 1990 (DS10/R-37S/200). Defeat in trade: victory in health. In: Chitanondh H, ed. Bangkok, Thailand: Health Promotion Institute, 2001.

20 Chaloupka F, Laixuthai A. Us trade policy and cigarette smoking in Asia. Cambridge, MA: National Bureau of Economic Research, 1996. https://www.nber.org/system/files/ working_papers/w5543/w5543.pdf

21 United Nations Treaty Collection. Chapter IX Health. 4. WHO Framework Convention on Tobacco Control. Geneva, 21 May 2003. Status as at 20-07-2021 [sic]. Available: https://treaties.un.org/pages/ViewDetails.aspx?src=TREATY\&mtdsg_no=IX-4\& chapter $=9 \&$ clang $=$ _en

22 Tan YL, Dorotheo U. The tobacco control atlas: ASEAN region, fourth edition, September 2018:93-101. FCTC Scoreboard. Southeast Asia tobacco control alliance (SEATCA). Bangkok: Thailand, 2021. https://seatca.org/tobacco-control-atlas/

23 United Nations Department of Economic and Social Affairs. Sustainable development goals: the 17 goals. Available: https://sdgs.un.org/goals [Accessed 20 May 2021]. 
24 Mackay JM. The tobacco industry in Asia: revelations in the corporate documents. Tob Control 2004;13 Suppl 2:ii1-3.

25 Assunta M. Global tobacco industry interference index 2019. Bangkok, Thailand: Global Center for Good Governance in Tobacco Control (GGTC), 2020. https:// exposetobacco.org/wp-content/uploads/GlobalTIIIndex2020_Report.pdf

26 Reyes JL. SEATCA tobacco industry interference index: implementation of article 5.3 of the who framework convention on tobacco control in Asian countries, 2020. Bangkok, Thailand: Southeast Asia Tobacco Control Alliance (SEATCA, 2020. https:// seatca.org/dmdocuments/SEATCA\%202020\%20TII\%20Index\%20in\%20Asian\% 20Countries.pdf

27 University of Bath. Stopping tobacco organisations and products (stop). Available: https://www.bath.ac.uk/projects/stopping-tobacco-organisations-and-products-stop/

28 New Straits Times. Review taxes on vape, urges industry body, 2020. Available: https:// www.nst.com.my/business/2020/12/649066/review-taxes-vape-urges-industry-body

29 Enquirer.net. Philippines warming up to better alternatives to cigarettes, 2020. Available: https://business.inquirer.net/314924/filipinos-warming-up-to-betteralternatives-to-cigarettes

30 Rossel S. Wake-up call. Tobacco Reporter, 2021. Available: https://tobaccoreporter. com/2021/02/01/wake-up-call/

31 Wongsamuth N, Wangkiat P. Bloomberg. Thailand sued over new cigarette warnings, 2013. Available: https://www.bangkokpost.com/thailand/politics/356881/publichealth-ministry-targeted-by-tobacco-firms

32 Shin H. Philip Morris sues South Korea over e-cigarette info disclosure. Reuters, 2018 Available: https://www.reuters.com/article/us-southkorea-philipmorris/philip-morrissues-south-korea-over-e-cigarette-info-disclosure-idINKCN1MB2KR

33 Visconti K. Tobacco firms WIN legal battles in pH. Rappler, 2012. Available: https:/ www.rappler.com/newsbreak/tobacco-firms-win-legal-battles-in-the-philippines

34 De Leon K, Sarita JT. The Philippines: pioneering the tobacco endgame. BMJ Blog 2020 https://blogs.bmj.com/tc/2020/01/13/the-philippines-pioneering-the-tobaccoendgame/

35 Guevara MW. The world's most widely smuggled legal substance. International Consortium of Investigative Journalists, 2008. Available: https://www.icij.org/ investigations/tobacco-underground/worlds-most-widely-smuggled-legalsubstance/

36 Collin J, Legresley E, MacKenzie R, et al. Complicity in contraband: British American tobacco and cigarette smuggling in Asia. Tob Control 2004;13 Suppl 2:ii104-11.

37 Assunta M, Fields N, Knight J, et al. "Care and feeding": the Asian environmental tobacco smoke consultants programme. Tob Control 2004;13 Suppl 2:ii4-12.

38 Sourcewatch. Whitecoats, 2009. Available: http://www.sourcewatch.org/index.php? title=Whitecoats [Accessed 28 Jan 2013].

39 Gaisch H. Philip Morris: organization of contacts with whitecoats, 1987. Available: http://www.tobaccofreedom.org/issues/documents/landman/whitecoats/index.htm/ [Accessed 28 Jan 2013].

40 Amul G, Tan G, Eijk Yvander. A systematic review of tobacco industry tactics in Southeast Asia: lessons for other low- and middle income regions. Int I Health Policy Manag 2020;10:324-37.

41 KPCW/BBC world news editorial: which countries do best — and worst - at keeping big tobacco out of politics, 2019. Available: https://www.kpcw.org/post/whichcountries-do-best-and-worst-keeping-big-tobacco-out-politics
42 Lee K, Eckhardt J. Looming threat of Asian tobacco companies to global health Lancet 2017:389:1958-60.

43 Murphy F. Rise of a new superpower: health and China's global trade ambitions. BMJ 2018:360:k595.

44 Stop COVID-19 monitoring brief: the tobacco industry its interests and allies, 2020. Available: https://www.generationsanstabac.org/wp-content/uploads/2020/11/Pourconsulter-lobservatoire-complet-de-STOP-anglais.pdf

45 STOP. Trading "Philanthropy" for Favors: Tobacco Industry CSR During COVID-19, 2020. Available: https://exposetobacco.org/news/ban-ti-csr/?utm_source=Stopping+ Tobacco+Organizations+and+Products+\%28STOP\%29\&utm_campaign= 891101c19c-Stop_Newsletter_8.25.20\&utm_medium=email\&utm_term=0 a7474fe40f-891101c19c-354163305\#utm_source=mailchimp\&utm_medium= email\&utm_campaign=covid-accountability

46 Tuoi Tre Online. Post-COVID-19 opens up many career opportunities for women [20 October 2020 in Vietnamese]. Available: https://tuoitre.vn/hau-covid-19-mo-ra-nhieuco-hoi-nghe-nghiep-cho-phu-nu-20201020092451325.htm. htm?fbclid=IwAROEBB9w277IfRE4vo_3P8Ah70hKQv8B6P0ZvqRXo1lkD2iZTA0Zan6dwCg

47 Azman NH. JTI Malaysia calls for concrete action against illicit cigarettes. Malaysian reserve. Available: https://themalaysianreserve.com/2020/11/02/jti-malaysia-calls-forconcrete-action-against-illicit-cigarettes/

48 Facebook of Mior Kamarul Mior Shahid, 2021. Available: https://www.facebook.com/ photo?fbid $=4159965954025202 \&$ set=pcb.4159996877355443 [Accessed 21 Jul 2021].

49 Bueno A. The hypocrisy of "CSR" in the time of COVID-19, 2021. Available: https:/l verafiles.org/articles/hypocrisy-csr-time-covid-19 [Accessed 21 Jul 2021]

50 Foundation for a smoke-free world. awarded grants. Available: https://www. smokefreeworld.org/awarded-grants/ [Accessed 20 May 2021]

51 SEATCA Statement on PMI's Foundation for a Smoke-free World, 2019. Available: https://seatca.org/seatca-statement-on-pmis-foundation-for-a-smoke-free-world/

52 Republic of the Philippines Department of Finance, Bureau of Internal Revenue, Quezon City. Revenue Memorandum Order No. 28-2014. Amendment to the revised code of conduct for revenue Officials and employees as implemented by revenue memorandum order (RMO) No. 53-2010 by prescribing the policies and guidelines on the protection of the Bureau of internal revenue (BIR) against tobacco industry interference pursuant to the joint memorandum circular No. 2010-01 of the civil service Commission and department of health. Available: https://www.bir.gov.ph/ images/bir_files/internal_communications_3/Full\%20Text\%20of\%20RM0\%202014/ RMO\%20No.\%2028-2014.pdf

53 Atlas Big. World tobacco production by country. Available: https://www.atlasbig.com/ en-gb/countries-by-tobacco-production [Accessed 30 Aug 2021].

54 STOP (Stopping Tobacco Organisations and Products). Tobacco industry accountability and liability in the time of COVID-19, 2020. Available: https://exposetobacco.org/ resource/hold-tobacco-accountable/ [Accessed 20 May 2021].

55 Who report on the global tobacco epidemic 2021: addressing new and emerging products. Geneva: World Health organization, 2021. Available: https://www.who.int/ teams/health-promotion/tobacco-control/global-tobacco-report-2021

56 United Nations Treaty Collection. 4. who framework convention on tobacco control, Geneva, 21 may 2003, 2021. Available: https://treaties.un.org/pages/ViewDetails. aspx?src=TREATY\&mtdsg_no=IX-4\&chapter $=9 \&$ clang=_en 